Al-Huquq: Journal of Indonesian Islamic Economic Law, 2 (2), 2020: 208-230

ISSN: 2715-0003; E-ISSN 2714-5514

DOI: http://dx.doi.org/10.19105/al\%20huquq.v li1.3166

\title{
Analisis Implementasi Pembiayaan Mudharabah dalam Perkembangan Hukum Ekonomi Syariah di Indonesia
}

\author{
Nufi Mu'tamar Almahmudi \\ (Pascasarjana IAIN Purwokerto Jl. Ahmad Yani No. 40A Purwokerto 53126)
}

\begin{abstract}
Abstrak:
Perbankan syariah saat ini mengalami perkembangan yang pesat di Indonesia. Akan tetapi dalam aplikasinya sebagian masyarakat masih berasumsi bahwa bank syariah hanyalah sebuah label yang digunakan untuk menarik simpati masyarakat muslim dalam bidang perbankan. Akad mudharabah menjadi salah satu produk yang digunakan di perbankan syariah. Tulisan ini mencoba menyajikan uraian terkait akad mudharabah dari konsep fikih klasik ke kontemporer dan penerapanya di bank syariah dengan menggunakan metode deskriptif analisis. Prinsip kehati-hatian merupakan sesuatu yang harus diperhatikan oleh perbankan dalam pemberian pembiayaan atau pendanaan, prinsip ini yang mengharuskan perbankan syariah memodifikasi konsep mudharabah, sehingga dapat diaplikasikan dan dikembangkan pada dunia perbankan pada kondisi kekinian. Adapun perbedaan konsep akad mudharabah dari teori ke praktek terlihat pada penentuan nisbah bagi hasil mudharabah, penetapan masa kontrak/ jangka waktu mudharabah, mempersyaratkan agunan, serta pihak yang menanggung kerugian. (Islamic banking is currently experiencing rapid development in Indonesia. However, in its application, some people still assume that Islamic banks are only a label that is used to attract the sympathy of the Muslim community in the banking sector. Mudharabah contract is one of the products used in Islamic banking. This paper tries to present a description of the mudharabah contract from the classical fiqh concept to the contemporary and its application in Islamic banks using descriptive analysis methods. The principle of prudence is something that must be considered by banks in the provision of financing or funding, this principle which requires Islamic banks to modify the concept of mudharabah, so that it can be applied and developed in the banking world to the present conditions. The difference in the concept of mudharabah

email koresponden: oppimutamar@gmail.com

https://creativecommons.org/licenses/by-nc/4.0/

Copyright (c) 2019 by al-huquq. All Right Reserved
\end{abstract}


Analisis Implementasi Pembiayaan Mudharabah dalam Perkembangan Hukum Ekonomi Syariah di Indonesia

contract from theory to practice can be seen in the determination of mudharabah profit sharing ratio, stipulation of the contract period/ mudharabah period, requiring collateral, and the party that bears the loss.)

\section{Kata Kunci:}

Analisis, Mudharabah, Hukum, Ekonomi, Syariah

\section{Pendahuluan}

Industri perbankan syariah telah mengalami perkembangan yang pesat. Dengan diterbitkannya Undang-undang Nomor 21 Tahun 2008 tentang Perbankan Syariah, pengembangan industri perbankan syariah nasional semakin memiliki landasan hukum yang memadai dan akan mendorong pertumbuhannya secara lebih cepat lagi. Seiring dengan pesatnya perkembangan itu, sebagian masyarakat masih berasumsi bahwa bank syariah hanyalah sebuah label yang digunakan untuk menarik simpati masyarakat muslim dalam bidang perbankan.

Mereka berpendapat bahwa bank syariah merupakan bank konvensional dengan istilah-istilah perbankan yang menggunakan istilah-istilah Islam, dengan kepala akad yang dibubuhi kalimat bismilahirrohmannirrohim dan pegawai yang mengenakan busana Islami dan mengucap salam, akan tetapi dalam pelaksanaan akad pada bank syariah masih menggunakan cara-cara yang dilarang oleh agama. Sikap skeptis dari masyarakat tentang perbankan syariah tersebut tidak dapat dipungkiri karena konotasi perbankan sejak dahulu memang terpisah secara nyata dengan syariah, sehingga pada awal pembentukan perbankan syariah banyak yang tidak percaya akan adanya keberhasilan para ekonom Islam dalam menyatukan institusi perbankan dengan syariah.1

Perbankan syariah dalam operasionalnya mempunyai berbagai macam produk baik penghimpunan dana maupun pembiayaan. Salah satu produk yang ditawarkan dalam perbankan syariah ini adalah dengan akad mudharabah. Tulisan ini berupaya mengulas bagaimana penerapan transaksi akad mudharabah di perbankan syariah.

\footnotetext{
1 Taufiqul Hulam, Jaminan Pada Transaksi Akad Mudharabah di Perbankan Syariah, Jurnal Mimbar Hukum, Vol. 22 No. 3 Oktober 2010, hlm. 521.
} 


\section{Metode Penelitian}

Penelitian ini merupakan riset kepustakaan (library research). Dalam hal ini, peneliti berbicara banyak, berdialog banyak dengan buku-buku, arsip-arsip, dokumen-dokumen, jurnal, catatan-catatan, dokumentasi-dokumentasi, surat-surat, dan lain-lain. ${ }^{2}$ Adapun dalam menganalisis penelitian ini penulis menggunakan metode deskriptif analisis. Analisis deskripsi bertujuan untuk memberikan deskripsi mengenai subyek penelitian berdasarkan data dan variabel yang diperoleh dari kelompok subyek yang diteliti. Data-data yang diperoleh kemudian penulis analisis dengan mengaitkan antara intstrumen non zakat dan implikasinya terhadap perekonomian.

\section{Pembahasan}

\section{Konsep Mudharabah}

Mudharabah dalam bahasa Arab merupakan bentuk wazan mufa'alah dari kata dharaba, yang berarti memukul dan melakukan perjalanan. ${ }^{3}$ Pengertian memukul atau berjalan ini lebih tepatnya adalah proses seseorang menggerakan kakinya dalam menjalankan usaha.

Zuhaily mengemukakan, mudharabah adalah akad kerja sama antara dua pihak: pihak pertama sebagai pemilik dana (shahibul mal) yang meyediakan seluruh modal; dan pihak kedua sebagai pengelola usaha (mudharib). Keuntungan yang didapatkan dari akad mudharabah dibagi menurut kesepakatan yang dituangkan dalam kontrak dan biasanya dalam bentuk presentase (nisbah). Jika usaha yang dijalankan mengalami kerugian maka kerugian itu ditanggung oleh pemilik modal (shahibul mal) sepanjang kerugian itu bukan kelalaian mudharib. Sementara mudharib menanggung kerugian atas upaya jerih payah dan waktu yang telah dilakukan untuk menjalankan

\footnotetext{
2 Bungaran Antonius Simanjutak, Metode Penelitian Sosial (Edisi Revisi) (Jakarta: Yayas an Pustaka Obor Indonesia, 2014), hlm. 8.

${ }^{3}$ Ahmad Sarwat, Fiqih Muamalat (Jakarta: Kampus Syariah, 2009), hlm. 106.
} 
Analisis Implementasi Pembiayaan Mudharabah dalam Perkembangan Hukum Ekonomi Syariah di Indonesia

usaha. Namun, jika kerugian itu diakibatkan karena kelalaian mudharib, maka mudharib harus bertanggung jawab atas kerugian tersebut. ${ }^{4}$

Sabiq menyatakan, mudharabah adalah akad antara dua belah pihak untuk salah satu pihak mengeluarkan sejumlah uang untuk diperdagangkan dengan syarat keuntungan dibagi dua sesuai perjanjian. Pendapat lain dikemukakan oleh AlJazairi, kerja sama dalam permodalan (mudharabah) atau pinjaman ialah si A memberikan sejumlah uang kepada si B untuk modal usaha dan keuntungannya dibagi antara keduanya sesuai dengan yang disyaratkan keduanya, sedang jika ada kerugian maka ditanggung oleh pemodal saja (si A), karena kerugian si B (pekerja) sudah cukup dengan kelelahan yang dialaminya. Oleh karena itu, ia harus dibebani dengan kerugian yang lain. ${ }^{5}$

Kontrak mudharabah juga merupakan suatu equity financing, tetapi mempunyai feature yang berbeda dibandingkan dengan musyarakah. Di dalam mudharabah hubungan kontrak bukan antara para pemberi modal, melainkan antara penyedia dana dengan entrepreneur. Di dalam kontrak mudharabah, seorang entrepreneur (dapat perorangan, rumah tangga, perusahaan, atau suatu unit ekonomi) memperoleh modal dari unit ekonomi lainnya untuk tujuan melakukan perdagangan atau perniagaan. Entrepeneur dalam kontrak ini menjadi "trustee" atas modal tersebut. Dia menggunakan modal tersebut untuk tujuan menghasilkan keuntungan. Kedua belah pihak telah menyetujui sebelumnya tentang cara pembagian keuntungan. Pada saat proyek sudah selesai entrepreneur mengembalikan modal tersebut kepada penyedia dana berikut porsi keuntungan yang telah disetujui

\footnotetext{
4 Ismail Nawawi, Fikih Muamalah Klasik dan Kontemporer, (Bogor: Ghalia Indonesia, 2012), hlm. 141.

${ }^{5}$ Ibid.
} 
sebelumnya. Dalam hal terjadi kerugian, maka seluruh kerugian dipikul oleh shahibul mal. ${ }^{6}$

\section{Dasar Hukum}

Mudharabah adalah akad yang dibolehkan dalam syariah Islam berdasarkan Al-Quran, As-Sunnah dan Ijma' para fuqaha. ${ }^{7}$ Dalil yang menjadi dasar hukum akad mudharabah adalah sebagai berikut:

1. Al-Quran Al-Kariem

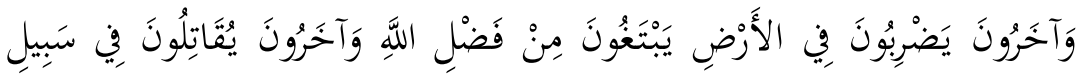

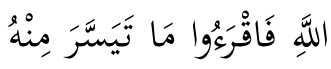

Artinya: Dia mengetahui bahwa akan ada di antara kamu orangorang yang sakit dan orang-orang yang berjalan di muka bumi mencari sebagian karunia Allah; dan orang-orang yang lain lagi yang berperang di jalan Allah, maka bacalah apa yang mudah (bagimu) dari al-Qur'an (QS. Al Muzammil : 20)

2. As-Sunnah

$$
\begin{aligned}
& \text { عَنِ ابْنِ عَبَّاسِ رَضِيَ اللهُ عَنْهُمَا أَنَّهُ قَالَ :كَانَ العَبّاسٌ بنِ عَبْدِ المُطَّلب رَضي }
\end{aligned}
$$

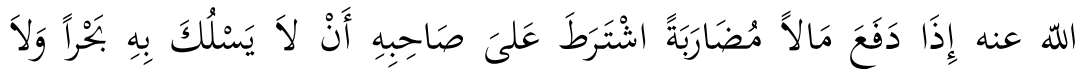

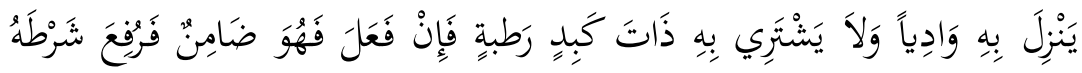

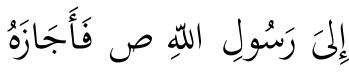

Artinya: Dari Ibnu Abbas RA bahwa Al-Abbas bin Abdil Mutthalib $R A$ bila menyerahkan harta secara mudharabah mensyaratkan kepada rekannya untuk tidak membawa harta itu melewati laut, atau menuruni lembah dan tidak membelanjakan hewan yang punya hati kering. Dia rekannya menyetujui syarat itu maka dia menjaminnya. Maka diangkatlah syarat itu kepada Rasulullah SAW dan beliau SAW membolehkannya (HR. Al-Baihaqi)

\footnotetext{
${ }^{6}$ Musthafa Kamal Pasha, dkk., Fikih Islam (Jogjakarta: Citra Karsa Mandiri, 2002), hlm. 370 .

${ }^{7}$ Ibid, hlm. 108-109.
} 
Analisis Implementasi Pembiayaan Mudharabah dalam Perkembangan Hukum Ekonomi Syariah di Indonesia

3. Ijma'

Kebolehan akad mudharabah ini dikuatkan dengan ijma', dimana diriwayatkan bahwa banyak diantara para shahabat Nabi SAW menyerahkan harta anak yatim dalam bentuk mudharabah. Di antara mereka adalah Umar bin AlKhattab, Utsman bin Al-Affan, Ali bin Abi Thalib, Abdullah bin Mas'ud, Abdullah bin Umar, Ubaidillah bin Umar, serta Aisyah ridhwanullahi alaihim. Dan tidak ada satu pun riwayat yang mengingkari adanya hal itu. Kaum muslimin sudah terbiasa melakukan akad kerja sama semacam itu hingga zaman ini di berbagai masa dan tempat tanpa ada ulama yang menyalahkannya. Ini merupakan konsensus yang diyakini umat, karena cara ini sudah digunakan bangsa Quraisy secara turun temurun dari jaman jahiliyah hingga zaman Nabi SAW. Terkait pembiayaan mudharabah Dewan Syariah Nasional MUI mengeluarkan Fatwa Dewan Syariah Nasional No: 07/DSNMUI/IV/2000 Tentang Pembiayaan Mudharabah (Qiradh).

4. Gambaran Konsep Fiqih

Mudharabah dalam fiqh adalah seseorang menyerahkan modal kepada pengusaha/ pekerja untuk di usahakan dengan syarat keuntungan dibagi sesuai kesepakatan yang telah ditetapkan dalam kontrak. Adapun kerugian sepenuhnya ditanggung pemilik pemodal. Mudharib (pengusaha) dalam hal ini akan memberikan kontribusi pekerjaan, waktu, fikiran dan tenaga dalam mengelola usaha sesuai ketentuan yang dicapai dalam kontrak, yaitu untuk mendapatkan keuntungan usaha yang akan dibagi berdasarkan kesepakatan.

Ada beberapa ketentuan-ketentuan yang ditetapkan dalam fiqh berkaitan dengan sistem mudharabah, diantaranya adalah sebagai berikut: ${ }^{2}$ Pertama: modal, modal dalam wacana

\footnotetext{
${ }^{8}$ Rahman Ambo Mase, Konsep Mudharabah Antara Kajian Fiqih dan Penerapan Perbankan, Jurnal Hukum Diktum, Volume 8 Nomor 1 Januari 2010, hlm. 79-81.
} 
fiqh diistilahkan dengan " $r a$ 'sul maal". Para ulama mensyaratkan bahwa modal itu harus memenuhi persyaratan:

1. Terdiri dari mata uang yang beredar atau berlaku. Pensyaratan ini diajukan untuk menghindari perselisihan dikemudian hari. Oleh karenanya tidak sah memudharabahkan harta dalam bentuk piutang, karena sulit untuk mengukur keuntungan darinya, dan dapat menimbulkan perselisihan dalam pembagian keuntungan.

2. Modal harus diserahkan sepenuhnya kepada pengusaha. Modal tersebut harus diserahkan seluruhnya pada saat ikatan kontrak.

3. Modal juga harus jelas jumlah dan jenisnya.

Kedua: manajemen, kontrak mudharabah dalam fiqh dibagi dalam dua kategori, yaitu:

1. Mudharabah Muthlaqah

Pengertiannya adalah sistem mudharabah dimana pemilik modal (investor/Shohib al Mal) menyerahkan modal kepada pengelola tanpa pembatasan jenis usaha, tempat dan waktu dan dengan siapa pengelola bertransaksi. Jenis ini memberikan kebebasan kepada Mudhorib (pengelola modal) melakukan apa saja yang dipandang dapat mewujudkan kemaslahatan. ${ }^{9}$ Dalam pembahasan fiqih salafus sholih seringkali dicontohkan dengan ungkapan if'al ma syi'ta (lakukanlah sesukamu) dari pemilik modal kepada pengelola modal yang memberi kekuasaan sangat besar. ${ }^{10}$

2. Mudharabah Muqayyadah (terbatas)

Pengertiannya pemilik modal (investor) menyerahkan modal kepada pengelola dan menentukan jenis usaha atau tempat atau waktu atau orang yang akan bertransaksi dengan mudharib. ${ }^{11}$

Dalam kontrak mudharabah, pihak pemodal atau investor tidak diperkenankan untuk ikut campur dalam mengelola

\footnotetext{
${ }^{9}$ Ahmad Sarwat, Fiqih Muamalat, hlm. 105.

10 Sri Sudiarti, Fiqh Muamalah Kontemporer (Medan: FEBI-UIN SU Press, 2018), hlm. 165.

${ }^{11}$ Ahmad Sarwat, Fiqih Muamalat, hlm. 105.
} 
Analisis Implementasi Pembiayaan Mudharabah dalam Perkembangan Hukum Ekonomi Syariah di Indonesia

manajemen usaha, ketika akad mudharabah telah diberlakukan, maka pihak mudharib (pengusaha) memiliki kewenangan penuh dalam mengelola usaha, terlepas apakah bentuk mudharabah yang dijalankan mutlaqah atau muqayaddah. Para fuqaha sepakat bahwa apabila pemodal ikut campur dalam manajemen usaha, maka secara otomatis kontrak mudharabah menjadi batal.

Ketiga: jaminan, esensi kontrak mudharabah adalah terjadinya kerjasama dan saling tolong menolong antara pemilik modal atau orang yang surplus modal dengan orang yang hanya memiliki keahlian dan ketrampilan, sehingga jurang pemisah antara kaya dan miskin dapat dikikis. Harta dalam presfektif Islam hanyalah merupakan titipan Tuhan yang seharusnya dikelola untuk kepentingan bersama dan untuk mewujudkan kesejahteraan bersama. Oleh karenanya, Islam menganjurkan harta itu tidak hanya berputar pada kelompok tertentu, tetapi harus dikembangkan dan diusahakan pada kegiatan-kegiatan ekonomi riil. Atas dasar itu, kontrak mudharabah tidak mensyaratkan adanya jaminan atas sejumlah modal yang diberikan kepada pengusaha (mudharib). Tolak ukur atas terjaminnya modal hanyalah kejujuran, sehingga kegiatan mudharabah harus diiringi dengan tingkat kejujuran yang tinggi dari mudharib.

Keempat: jangka waktu, mengenai pembatasan jangka waktu mudharabah diperdebatkan oleh para ahli fiqh. Sebagian ulama berpendapat bahwa dengan adanya batasan waktu berlakunya kontrak akan menjadikan kontrak itu batal, sebab hal tersebut dapat menghilangkan kesempatan pengusaha untuk mengembangkan usahanya, sehingga keuntungan maksimal dari kegiatan itu sulit untuk tercapai. Sedangkan sebagian yang lain beranggapan bahwa boleh saja terjadi kesepakatan antara pemodal dan pengusaha mengenai jangka waktu mudharabah, dengan catatan apabila salah satu pihak ingin mengundurkan diri dari ikatan kontrak harus terlebih dahulu memberitahu yang lainnya. 
Kelima: nisbah keuntungan, nisbah keuntungan merupakan rukun khas yang ada pada akad mudharabah, hal inilah yang membedakannya dengan akad-akad yang lain. Nisbah ini merupakan bagian yang akan diperoleh oleh masing-masing pihak yang berkontrak. Penetapan nisbah dilakukan diawal dan dicantunkan dalam akad. Dalam proses tersebut, boleh jadi terjadi tawar menawar dan negosiasi pembagian nisbah. Negosiasi dilakukan dengan prinsip musyawarah dan antaradin minkum (saling ridha).

Keenam: bentuk mudharabah, dalam kajian fiqh klasik, bentuk mudharabah yang dijalankan dalam akad dilakukan dengan modus pembiayaan/ investasi langsung (direct financing), dimana shahibul maal bertindak sebagai surplus unit melakukan investasi langsung kepada mudharib yang bertindak sebagai deficit unit. Ciri dari model mudharabah ini adalah, biasanya hubungan antara shahibul maal dengan mudharib merupakan hubungan personal dan langsung serta transaksi dilandasi saling kepercayaan (amanah).

\section{Aplikasi Mudharabah di Bank Syariah}

Sebagai ilustrasi transaksi syariah yang mempergunakan akad mudharabah dapat dilihat sebagai berikut:

Shahibul maal yang bermitra dengan mudharib untuk usaha percetakan selama enam bulan. Shahibul maal memberikan uang untuk modal usaha sebesar Rp 30 juta dan kedua belah pihak sepakat dengan nisbah bagi hasil 40:60 (40\% keuntungan untuk shahibul maal). Setelah menjalankan usaha selama enam bulan, modal usaha telah berkembang menjadi Rp 50 juta, sehingga mudharib memperoleh keuntungan sebesar Rp 20 juta (Rp 50 juta - Rp 30 juta). Maka sesuai perjanjian yang telah dibuat di awal shahibul maal berhak mendapatkan 
Analisis Implementasi Pembiayaan Mudharabah dalam Perkembangan Hukum Ekonomi Syariah di Indonesia

keuntungan sebesar Rp 8 juta (40\% x Rp 20 juta) dan sisanya Rp 12 juta menjadi hak mudharib. 12

Gambaran di atas merupakan penerapan akad mudharabah untuk pembiayaan modal kerja, dan diperkenankan memberikan modal dalam bentuk uang. Selain itu, terdapat pula produk-produk turunan atau produk penghimpunan dana dari masyarakat (funding), ${ }^{13}$ berikut uraiannya:

\section{Giro Mudharabah}

Yang dimaksud dengan giro mudharabah adalah giro yang dijalankan berdasarkan prinsip mudharabah. Prinsip mudharabah mempunyai dua bentuk, yakni mudharabah mutlaqah dan mudharabah muqayyadah. Perbedaan utama dari kedua bentuk mudharabah itu terletak pada ada atau tidaknya persyaratan yang diberikan pemilik dana kepada bank dalam mengelola dananya, baik dari sisi waktu, tempat maupun objek investasinya. Dalam hal ini bank syariah bertindak sebagai mudharib (pengelola dana) sedangkan nasabah bertindak sebagai shahibul maal (pemilik dana).

Nasabah pemilik rekening giro mudharabah berhak memperoleh bagi hasil sesuai dengan nisbah yang telah disepakati di awal pembukaan rekening. Bank syariah menanggung semua biaya operasional giro dengan menggunakan nisbah bagi hasil yang menjadi haknya. Di samping itu bank syariah tidak diperkenankan mengurangi nisbah nasabah tanpa persetujuan nasabah. Sesuai dengan ketentuan yang berlaku, PPH bagi hasil giro mudharabah dibebankan langsung ke rekening giro mudharabah pada saat perhitungan bagi hasil.

Rekening giro mudharabah ini hanya bisa dimiliki oleh para pengusaha yang memiliki aliran keuangannya

12 http://www.syariahbank.com/contoh-akad-mudharabah/?amp, diakses 3 April 2019.

13 Nofinawati, Akad dan Produk Perbankan Syariah, Jurnal Fitrah, Vol. 08 No. 2 Juli-Des ember 2014, hlm 224-227. 
rutin cuma beberapa kali saja dalam kurun waktu tertentu. Karena dalam akad mudharabah jangka waktu investasi harus jelas, agar perhitungan bagi hasilnya lebih mudah dilakukan oleh bank syariah selaku pihak pengelola dana yang dinvestasikan oleh nasabah.

2. Tabungan Mudharabah

Tabungan mudharabah merupakan salah satu produk penghimpunan dana oleh bank syariah yang menggunakan akad mudharabah muthlagah. Sama halnya dengan giro mudharabah, dalam tabungan mudharabah, bank syariah juga bertindak sebagai mudharib (pengelola dana) sedangkan nasabahnya bertindak sebagai shahibul maal (pemilik dana). Bank syariah memiliki kebebasan dalam mengelola dana, dengan kata lain nasabah tidak ada memberikan batasan-batasan kepada bank syariah dalam mengelola dananya. Setelah bank syariah mengelola dana nasabah, maka insya Allah bank syariah akan memperoleh keuntungan dari investasi yang dilakukannya. Setelah bank syariah mendapatkan keuntungan, maka bank syariah juga akan membagi keuntungan tersebut dengan nasabahnya. Sesuai dengan kesepakatan nisbah bagi hasil di awal pembukaan rekening.

Sesuai dengan akad yang digunakannya yaitu mudharabah, maka dana tabungan mudharabah sifatnya berjangka. Dengan begitu jangka waktunya harus jelas dan disepakati di awal, sehingga dana tabungan mudharabah tidak bisa ditarik kapan saja si nasabah membutuhkannya. Contoh produknya adalah tabungan haji, tabungan pendidikan dan lain-lain.

3. Deposito Syariah

Selain giro dan tabungan syariah, produk perbankan syariah lainnya yang termasuk produk penghimpunan dana (funding) adalah deposito. Adapun yang dimaksud dengan deposito syariah adalah deposito 
Analisis Implementasi Pembiayaan Mudharabah dalam Perkembangan Hukum Ekonomi Syariah di Indonesia

yang yang dijalankan berdasarkan prinsip syariah. Dalam hal ini, Dewan Syariah Nasional (DSN) MUI telah mengeluarkan fatwa yang menyatakan bahwa deposito yang dibenarkan adalah deposito yang berdasarkan prinsip mudharabah.

Deposito merupakan dana nasabah yang ada pada bank yang penarikannya dapat dilakukan pada saat jatuh tempo atau jangka waktu yang ditentukan. Misalnaya 3 bulan, 6 bulan, dan seterusnya. Pada produk deposito ini bank menggunakan prinsip bagi hasil.

Sama halnya dengan giro dan tabungan mudharabah, bank syariah juga bertindak sebagai mudharib (pengelola dana) sedangkan nasabahnya bertindak sebagai shahibul maal (pemilik dana). Apabila yang diterapkan dalam penghimpunan dana menggunakan akad mudharabah mutlaqah maka berdasarkan prinsip ini tidak ada pembatasan bagi bank dalam menggunakan dana yang dihimpun. ${ }^{14}$ Namun apabila akad yang digunakan mudharabah muqayyadah, maka bank syariah tidak akan bisa memiliki kebebasan dalam mengelola dana nasabah.

Sama halnya dengan giro dan tabungan mudharabah, setelah bank syariah mengelola dana nasabah, maka insya Allah bank syariah akan memperoleh keuntungan dari investasi yang dilakukannya. Setelah bank syariah mendapatkan keuntungan, maka bank syariah juga akan membagi keuntungan tersebut dengan nasabahnya. Sesuai dengan kesepakatan nisbah bagi hasil di awal pembukaan rekening.

${ }^{14}$ Muhamad, Sistem Bagi Hasil dan Pricing Bank Syariah (Yogyakarta:UII Press, 2016), hlm. 7. 


\section{Penyaluran Dana.}

Pembiayaan mudharabah adalah akad kerjasama usaha antara dua pihak dimana pihak pertama pemilik modal (shahibul maal) menyediakan seluruh (100\%) modal, sedangkan pihak lainnya menjadi pengelola (mudharib). Keuntungan usaha secara mudharabah dibagi menurut kesepakatan yang dituangkan dalam kontrak, sedangkan apabila rugi ditanggung oleh pemilik modal selama kerugian itu bukan akibat kelalaian si pengelola. Seandainya kerugian ini diakibatkan karena kecurangan atau kelalaian si pengelola, si pengelola harus bertanggung jawab atas kerugian tersebut. ${ }^{15}$ Dengan demikian bank selaku pemilik modal menanggung seluruh kerugian kecuali akibat kelalaian dan penyimpangan pihak nasabah, seperti penyelewengan, kecurangan dan penyalahgunaan dana. ${ }^{16}$

Akad mudharabah secara umum terbagi menjadi dua jenis yaitu Mudharabah Muthlaqah dan Mudharabah Muqayyadah. Yang dimaksud dengan Mudharabah Muthlaqah adalah bentuk kerjasama antara shahibul maal dan mudharib yang cakupannya sangat luas dan tidak dibatasi oleh spesifikasi jenis usaha, waktu, dan daerah bisnis. Sedangkan Mudharabah Muqayyadah adalah bentuk kerjasama antara shahibul maal dan mudharib dimana mudharib memberikan batasan kepada shahibul maal mengenai tempat, cara, dan obyek investasi. ${ }^{17}$ Dalam dunia perbankan Mudharabah biasanya diaplikasikan pada produk pembiayaan atau pendanaan seperti pembiayaan modal kerja. ${ }^{18}$ Selain itu juga diterapkan untuk investasi khusus, disebut juga mudharabah muqayyadah, dimana sumber dana khusus dengan

\footnotetext{
15 Nofinawati, Akad dan Produk Perbankan Syariah, hlm. 231.

16 Abdul Manan, Hukum Ekonomi Syariah Dalam PerspektifKewenangan Peradilan Agama (Jakarta: Kencana, 2012), hlm. 222.

17 Nofinawati, Akad dan Produk Perbankan Syariah, hlm. 231.

18 Faozan Amar, Ekonomi Islam: Suatu Pengantar, (Jakarta: Uhamka Press, 2016), hlm. 81 .
} 
Analisis Implementasi Pembiayaan Mudharabah dalam Perkembangan Hukum Ekonomi Syariah di Indonesia

penyaluran yang khusus dengan syarat-syarat yang telah ditetapkan oleh shahibul maal. ${ }^{19}$

\section{Analisis Pembiayaan Mudharabah dari Konsep Fikih dan Implementasinya di Perbankan Syariah Penentuan Nisbah Bagi Hasil}

Pada prakteknya di perbankan syariah, akad mudharabah mengalami beberapa transformasi dari konsep fikih ke akad perbankan. Dalam penentuan nisbah bagi hasil. Bank syariah menjalin persetujuan dengan klien mudharabah-nya atas dasar rasio pembagian hasil yang ditentukan saat kontrak. Rasio bagi hasil ini bergantung pada kekuatan bargaining nasabah, prediksi laba mudharabah, tingkat bunga di pasar bank konvensional, karakteristik nasabah, marketabilitas barang dagangan atau prospek usaha, dan juga jangka waktu yang digunakan. ${ }^{20}$ Nisbah bagi hasil harus disepakati di awal kontrak dengan proporsi kedua belah pihak jika dijumlahkan menjadi $100 \%$.

Sebagaimana Ibn Rusdy menegaskan bahwa kontrak mudharabah harus menyepakati adanya pembagian hasil bagi tiap-tiap pihak. Tingkat pembagian tersebut harus berdasarkan rasio persentase dan bukan jumlah yang ditentukan. Sebelum tiba saatnya perhitungan laba, kerja sama mudharabah harus diwujudkan dalam bentuk uang dan modal yang harus disisihkan. Mudharib dituntut untuk tidak mencampurkan semua barang-barang bisnis mudharib yang merupakan pengembangan dari modal pokok mudharabah. ${ }^{21}$ Akan tetapi, kenyataan menunjukkan bahwa proses tawar menawar dan negosiasi pembagian nisbah hanya dilakukan terhadap deposan/investor dengan jumlah dana besar, karena mereka

\footnotetext{
${ }^{19}$ Muhammad Syafii Antonio, Bank Syariah: Dari Teori ke Praktik (Jakarta: Gema Insani, 2001), hlm. 97.

${ }^{20}$ Muhammad, Manajemen Pembiayaan Mudharabah Di Bank Syariah, (Jakarta: Rajawali, 2008), hlm. 90.

${ }^{21} \mathrm{Ibid}$.
} 
memiliki daya tawar yang relatif tinggi, sehingga dapat diberikan spesial nisbah. Sedangkan terhadap deposan kecil, biasanya tawar-menawar tidak terjadi, akan tetapi pihak bank yang menawarkan nisbah yang telah jadi, sehingga deposan boleh setuju atau tidak 22

Dengan demikian, meskipun terjadi tawar menawar dalam penentuan nisbah bagi hasil, bank syariah lebih dominan perannya. Karena mudharib akan mengikuti pilihan nisbah bagi hasil yang ditawarkan oleh bank syariah sesuai dengan ketentuan/ acuan yang ada. Setelah nisbah bagi hasil disepakati, maka nisbah bagi hasil tersebut bersifat tetap sesuai jangka waktu yang disepakati. Akan tetapi, perlu digarisbawahi bahwa dalam pengelolaan usaha tentunya keuntungan yang didapat mudharib tidak selalu tetap. Bagi hasil tetap ini lebih ditujukan untuk mempermudah penghitungan di bank syariah.

\section{Mempersyaratkan Agunan}

Kaitannya dengan agunan ini, bank syariah mengambil beberapa langkah untuk meyakinkan bahwa modal dan keuntungan yang akan diperolehnya harus kembali dengan tepat waktu sebagaimana yang sudah ditetapkan dalam kontrak. Secara umum hal ini dapat dicapai dengan media garansi (jaminan) baik dari mudharib atau dari pihak ketiga.

Diskursus dalam praktik transaksi mudharabah yang di dalamnya terdapat kewajiban mudharib untuk memberikan jaminan masih juga terjadi perbedaan pendapat di kalangan ulama. Menurut ulama klasik dalam perjanjian mudharabah tidak diperlukan dan tidak dibenarkan adanya jaminan. Tidak etis bagi lembaga keuangan syariah meminta jaminan dalam hal perjanjian kerja sama mudharabah. Hal ini didasarkan pada pemahaman bahwa transaksi mudharabah terjadi karena adanya kepentingan bersama untuk bermitra usaha yang didasarkan

\footnotetext{
${ }^{22}$ Rahman Ambo Mase, Konsep Mudharabah,hlm. 83.
} 
Analisis Implementasi Pembiayaan Mudharabah dalam Perkembangan Hukum Ekonomi Syariah di Indonesia

pada sikap saling membutuhkan dan saling percaya dan terjadinya mudharabah bilamana pemilik modal sudah merasa yakin dan percaya atas diri orang yang akan mengelola modalnya itu. Karenanya jaminan yang dibebankan pada pengelola modal dinilai tidak mencerminkan nilai mudharabah yang sesungguhnya. ${ }^{23}$

Problem jaminan ini sesungguhnya dalam teori fikih yang dikembangkan para ulama mazhab telah jelas bahwa shahibul mal tidak dapat menuntut jaminan apa pun dari mudharib untuk mengembalikan modal pokok atau modal plus laba. Ketika kontrak kerja sama antara shahibul mal dan mudharib ditetapkan bahwa satu pihak yang menanggung modal dan pihak lain adalah orang yang diberi kepercayaan kerja maka garansi tersebut harus ditiadakan. Jika shahibul mal memaksa adanya jaminan dan menjadikannya sebagai term dari sebuah kontrak maka kontrak kerja sama tersebut menjadi bathl. Hal demikian menurut Imam Malik dan Syafi'i. ${ }^{24}$

Dalam perkembangannya pada praktik ekonomi modern dalam transaksi mudharabah khususnya di Indonesia seorang mudharib akan dibebani dengan jaminan. Hal ini sebagaimana diatur dalam ketentuan Bank Indonesia sebagaimana yang dituangkan dalam Peraturan Bank Indonesia Nomor: 7/46/PBI/2005 Pasal 6 huruf (o) yang menjelaskan bahwa: Bank dapat meminta jaminan atau agunan untuk mengantisipasi risiko apabila nasabah tidak dapat memenuhi kewajiban sebagaimana dimuat dalam akad karena kelalaian dan/atau kecurangan.

Selain itu, diwajibkannya jaminan dalam transaksi mudharabah terdapat dalam Fatwa Dewan Syariah Nasional Nomor: 07/DSN-MUI/IV/2000 tentang Pembiayaan

${ }^{23}$ Taufiqul Hulam, Jaminan, hlm. 530-531.

${ }^{24}$ Ibnu Rusyd, Bidayah Al Mujtahid wa Nihayah Al Muqtashid, (Semarang: AySyifa, 1990), hlm.179, dikutip Muhammad Hamzah, Analisis Transformasi Akad Mudharabah Klasik ke Akad Mudharabah Kontemporer di Perbankan Syariah (Banjarmasin: UIN Antasari, 2016), hlm. 111. 
mudharabah yang menyatakan bahwa pada prinsipnya, dalam pembiayaan mudharabah tidak ada jaminan, namun agar mudharib tidak melakukan penyimpangan Lembaga Keuangan Syariah dapat meminta jaminan dari mudharib atau pihak ketiga. ${ }^{25}$

Ditetapkannya jaminan dalam transaksi mudharabah lebih didasarkan pada penerapan metode ijtihad yang tidak dalam maksud mengesampingkan dari hukum asalnya namun lebih didasarkan pada prinsip penggunaan metode istihsan. Metode ini pada prinsipnya mengutamakan tujuan untuk mewujudkan kemaslahatan-kemaslahatan atau menolak bahaya-bahaya secara khusus sebab dalil umum menghendaki dicegahnya bahaya itu. ${ }^{26}$ Dahulu orang masih terikat dan tunduk pada nilainilai ajaran Islam dengan baik sehingga kecenderungan untuk berbuat jahat dalam setiap transaksi (muamalah) sangat kecil bahkan hampir tidak ada karena ketakutannya bahwa perbuatan jahat itu bertentangan dengan ajaran Islam yang dianutnya. Namun demikian, dalam perkembangan transaksi modern kecenderungan untuk berbuat jahat dalam sebuah transaksi itu besar. Oleh karenanya perlu diwaspadai dan diantisipasi agar kejahatan itu tidaklah terjadi. Permintaan jaminan dalam transaksi mudharabah lebih didasarkan pada penerapan prinsip kehati-hatiannya agar tidak terjebak dalam praktik yang curang/jahat itu. Sehingga dalam transaksi ini lebih ditekan kemungkinan risiko-risiko yang terjadi dan kemaslahatan dapat terwujud dengan baik dalam praktik mudharabah itu.

Akan tetapi dengan dipersyaratkanya jaminan dalam pembiayaan mudharabah menimbulkan permasalahan tersendiri bagi para pengusaha karena tidak semua pengusaha mempunyai jaminan yang dipersyaratkan oleh pihak bank. Di

\footnotetext{
25 Taufiqul Hulam, Jaminan, hlm. 530-531.

26 Iskandar Usman, Istihsan dan Pembaharuan Hukum Islam, (Jakarta: Raja Grafindo Persada, 1994), hlm. 20.
} 
Analisis Implementasi Pembiayaan Mudharabah dalam Perkembangan Hukum Ekonomi Syariah di Indonesia

sisi lain, jaminan dalam pembiayaan mudharabah yang dipraktekan di bank syariah menjadi syarat yang harus dipenuhi. Padahal pada prinsipnya pembiayaan mudharabah tidak ada jaminan, sehingga tidak semestinya jaminan menjadi syarat mutlak dalam pembiayaan mudharabah. Dengan demikian, konsep akad mudharabah yang awalnya kerjasama dengan sistem saling percaya menjadi di kesampingkan dan dari praktek tersebut terlihat bahwa bank syariah tidak siap dengan resiko kerugian yang merupakan konsekuensi dari akad mudharabah.

\section{Penetapan Masa Kontrak}

Di perbankan syariah jangka waktu pembiayaan atas dasar akad mudharabah, pengembalian dana, dan pembagian hasil usaha ditentukan berdasarkan kesepakatan bank dan nasabah. Pengembalian pembiayaan atas dasar mudharabah dilakukan dalam dua cara, yaitu secara angsuran ataupun sekaligus pada akhir periode akad, sesuai dengan jangka waktu pembiayaan atas dasar akad mudharabah. ${ }^{27}$

Kajian fikih tentang pembatasan waktu usaha terjadi perbedaan pendapatan dikalangan mazhab. Menurut mazhab maliki dan syafi'i, pembatasan waktu usaha seperti ini dapat menyebabkan kontrak menjadi tidak valid. Namun demikian, kedua mazhab ini membolehkan sebuah klausul tentang waktu perjanjian. ${ }^{28}$ Kejelasan waktu kontrak merupakan bagian yang penting dalam perbankan syariah, maka akhirnya teori fikih mudharabah diadaptasikan dengan sistem yang berlaku. Penyesuaian ini diaplikasikan dengan menyediakan pilihan-pilihan jangka waktu yang sudah di tetapkan bank sebelumnya kepada mudharib. Kesepakatan masalah jangka waktu investasi ini tidak dimusyawarahkan sebelumnya antara kedua pihak, tetapi mudharib disuruh

\footnotetext{
27 Wiroso, Produk Perbankan Syariah (Jakarta: LPFE Usakti, 2009), hlm. 330.

${ }^{28}$ Muhammad, Manajemen Pembiayaan Mudharabah, hlm. 43.
} 
memilih jangka waktu yang sudah ditentukan oleh bank. Pendek kata pemilihan jangka waktu yang selain ditawarkan tidak dapat diterima oleh bank. Disamping penentuan jangka waktu yang ditetapkan bank, pada kenyataan perbankan syariah menyepakati pilihan jangka waktu mudharib tersebut berdasarkan kriteria khusus, tingkat kekhawatiran terhadap karakter dan kredibilitas mudharib. Oleh karena itu, jangka waktu yang di berikan oleh pihak bank belum tentu sesuai dengan kemampuan mudharib untuk mengembalikan modal ke pihak bank.

\section{Pihak yang Menanggung Kerugian}

Tugas mudharib dalam menjalankan usaha meliputi pengelolaan, penyimpanan, dan pemasaran, sehingga mudharib harus memanajerial dengan baik dan teliti atas modal yang dipercayakan kepadanya. Mudharib menjamin dalam mengelola barang tersebut sesuai dengan ketentuan yang telah disepakati dalam pembiayaan mudharabah. Ia bertanggung jawab untuk menanggung segala kerugian yang disebabkan oleh kesalahannya sendiri yang menyimpang dari prosedur penentuan kontrak. Pihak bank tidak menanggung kerugian yang disebakan oleh kesalahan pihak mudharib. Singkatnya, mudharib harus tunduk terhadap segala persyaratan yang telah ditentukan dalam kontrak yang berkaitan dengan pengelolaan usaha. Pelaksanaan tersebut umumnya diawasi oleh pihak bank. ${ }^{29}$ Adapun dalam kerugian mudharabah perlu diketahui halhal sebagai berikut:

1. Sebagaimana disebutkan di atas, kerugian hanya akan ditanggung oleh pemilik dari dana, namun Pengelola Dana tidak akan menanggung a pa pun darinya terkecuali apabila hal ini terjadi karena pelanggaran dari pihaknya atas dana atau kelalaiannya ditinjau dari perjanjian Fuqaha atau kesepakatan Fuqaha mengenai kesepakatan ini.

\footnotetext{
${ }^{29}$ Rahman Ambo Mase, Konsep Mudharabah, hlm. 85.
} 
Analisis Implementasi Pembiayaan Mudharabah dalam Perkembangan Hukum Ekonomi Syariah di Indonesia

2. Kerugian akhir neto pada saat Mudharabah diputarkan kembali akan dianggap sebagai penurunan dalam modal Mudharabah, dan Pengelola Dana akan mengembalikan sisanya setelah mengurangkan kerugian sesuai dengan perjanjian kesepakatan Fuqaha.

3. Kerugian berkala atau sewaktu-waktu, yang terjadi pada masa kelangsungan Mudharabah harus diperhitungkan dengan keuntungan yang diperoleh sebelumnya yang belum dibagikan di antara kedua belah pihak, jika ada sesuai dengan ketentuan perjanjian Fuqaha.

4. Kerugian sewaktu-waktu yang tidak ditutup oleh keuntungan yang diperoleh sebelumnya harus ditangguhkan sampai terdapat realisasi keuntungan setelahnya dan diperhitungkan dengannya, dan keuntungan semacam ini tidak akan dibagikan, terkecuali setelah kerugian-kerugian tersebut di atas telah diganti rugi. Apabila tidak terdapat keuntungan yang diperoleh setelahnya atau apabila keuntungan yang diperoleh tidak cukup untuk menutup kerugian ini sampai akhir dari jangka waktu tersebut, maka kerugian tersebut akan diperlakukan sebagai atau dengan mengacu kepada butir 2 diatas. Apabila kerugian sewaktu-waktu terjadi selama kelangsungan Mudharabah, dan keuntungan yang diperoleh sebelumnya telah dialokasikan, maka kerugian semacam ini akan diganti rugi dari keuntungan tersebut: sesuai dengan ketentuan ketidak konsistensi keuntungan yang dibagikan. Hal ini adalah untuk mengatakan bahwa Pengelola Dana harus mengembalikan keuntungan yang telah ia peroleh untuk menutup kerugian ini, dan keuntungan yang diambil oleh pemilik dari dana tersebut harus dihitung sebagai penarikan dari bagian modalnya sesuai dengan ketentuan kepemilikan keuntungan.

5. Kerugian dari dana Mudharabah yang kerugiannya disebabkan oleh kerusakan atau sebab-sebab lainnya selain daripada sebab praktek kegiatan usahanya sendiri, akan diperlakukan sebagai kerugian modal apabila semua dari dana itu telah rugi sebelum atau setelah mulainya kegiatan usaha tersebut dan apabila juga sebagian darinya telah 
merugi sebelum mulainya kegiatan usaha tersebut, maka sesuai dengan kaidah penggandaan Fuqaha, terkecuali bagi Safii dan apabila bagiannya tersebut merupakan kerugian setelah dimulainya kegiatan usaha akan diperlakukan sebagai suatu kerugian biasa.

6. Pengaturan atau kaidah sehubungan dengan pelanggaran oleh Pengelola Dana dalam kegiatannya terhadap ketentuan atau tujuan atau persyaratan kontrak atau batasan-batasan yang dibuat terhadapnya oleh pemilik dari dana tersebut: dalam hal ini ia akan menjadi seorang pelanggar dan kepemilikanatas dananya sebagai trust atau wali akan berubah menjadi suatu agunan, yakni jumlah akan diubah dari Mudharabah menjadi suatu hutang oleh Pengelola Dana tersebut. Apabila ia mengalihkan dana tersebut bertentangan dengan ketentuan dan melakukan pelanggaran itu, dan ia memperoleh keuntungan, maka sesuai dengan kebijakan Fuqaha, semua keuntungan tersebut akan menjadi milik dari pemilik dana, sedangkan menurut pendapat lainnya adalah bahwa itu harus merupakan milik Pengelola Dana dan beberapa lainnya mengatakan bahwa keuntungan akan tetap merupakan keuntungan bersama bagi kedua belah pihak tersebut.

7. Pengaturan sehubungan dengan pencabutan (penghapusan) Mudharabah: Mudharabah dicabut kembali karena tiadanya salah satu dari ketentuan atau syaratsyarat tersebut. Salah satu dari peraturan tersebut mengatakan, bahwa dana tersebut akan tetap merupakan kepercayaan atau perwalian pada kepemilikan.

8. Pengelola Dana, karena ia akan menjadi karyawan, dan tindakannya sehubungan dengan dana Mudharabah yang telah dicabut kembali dapat sah atau berlaku. Dalam hal suatu keuntungan diperoleh dari tindakan semacam ini, beberapa ketentuan Fuqaha mengatakan, bahwa semua keuntungan tersebut harus menjadi milik dari pemilik dana dan Pengelola Dana akan menerima pembayaran sejumlah yang sama dan beberapa Fuqaha mengatakan bahwa Pengelola Dana harus menerima kurang dari 
Analisis Implementasi Pembiayaan Mudharabah dalam Perkembangan Hukum Ekonomi Syariah di Indonesia

pembayaran yang sama atau bagian dari keuntungan yang disebutkan di dalam kontrak. ${ }^{30}$

Dengan demikian, perbankan syariah tidak serta merta menanggung segala kerugian dari pembiayaan mudharabah. Akan tetapi kerugian yang diakibatkan karena kelalaian mudharib maka ia yang harus menanggung kerugian tersebut. Dalam kasus tersebut, barang jaminan yang dijadikan sarana pertanggungjawaban harus diberikan kepada bank, sehingga mudharib tidak hanya rugi secara waktu, tenaga, dan fikiran, akan tetapi juga rugi secara materi yaitu barang yang menjadi jaminan.

\section{Kesimpulan}

Dari paparan diatas dapat disimpulkan bahwa ada perbedaan mendasar konsep mudharabah yang tertuang dalam kajian fiqh klasik dengan yang diperaktekkan pada perbankan syariah. Perbedaan tersebut terlihat pada penentuan nisbah bagi hasil mudharabah, mempersyaratkan agunan, penetapan masa kontrak/ jangka waktu mudharabah, serta pihak yang menanggung kerugian.

Prinsip kehati-hatian merupakan sesuatu yang harus diperhatikan oleh perbankan dalam pemberian pembiayaan atau pendanaan, prinsip ini yang mengharuskan perbankan syariah memodifikasi konsep mudharabah, sehingga dapat diaplikasikan dan dikembangkan pada dunia perbankan dan memberi kemaslahatan. Perbedaan mendasar yang terjadi tidak menimbulkan pengkerdilan akan konsep fiqh klasik, tapi konsep tersebut diterapkan sesuai dengan kondisi kekinian. Apa yang dikembangkan oleh dunia perbankan akan konsepkonsep muamalah dalam fiqh klasik adalah merupakan penerapan akan prinsip ijtihad.

${ }^{30}$ Wiroso, Produk Perbankan Syariah, hlm. 338-340. 


\section{Daftar Pustaka}

Amar, Faozan. Ekonomi Islam: Suatu Pengantar. Jakarta: Uhamka Press. 2016.

Antonio, Muhammad Syafii. Bank Syariah: Dari Teori ke Praktik. Jakarta: Gema Insani, 2001.

Hulam, Taufiqul. Jaminan Pada Transaksi Akad Mudharabah di Perbankan Syariah, Jurnal Mimbar Hukum Vol. 22 No. 3 Oktober 2010.

Http:/ / www.syariahbank.com/contoh-akad-mudharabah/?amp, diakses 3 April 2019.

Manan, Abdul. Hukum Ekonomi Syariah Dalam Perspektif Kewenangan Peradilan Agama. Jakarta: Kencana. 2012.

Mase, Rahman Ambo. Konsep Mudharabah Antara Kajian Fiqih dan Penerapan Perbankan, Jurnal Hukum Diktum Volume 8 Nomor 1 Januari 2010.

Muhammad. Manajemen Pembiayaan Mudharabah Di Bank Syariah. Jakarta: Rajawali. 2008.

Muhamad. Sistem Bagi Hasil dan Pricing Bank Syariah. Yogyakarta:UII Press. 2016.

Nawawi, Ismail. Fikih Muamalah Klasik dan Kontemporer. Bogor: Ghalia Indonesia. 2012.

Nofinawati. Akad dan Produk Perbankan Syariah. Jurnal Fitrah Vol. 08 No. 2 Juli-Desember 2014.

Pasha, Musthafa Kamal, dkk. Fikih Islam. Jogjakarta: Citra Karsa Mandiri. 2002.

Rusyd, Ibnu. Bidayah Al Mujtahid wa Nihayah Al Muqtashid. Semarang: Ay-Syifa. 1990.

Sarwat, Ahmad. Fiqih Muamalat. Jakarta: Kampus Syariah. 2009. Simanjutak, Bungaran Antonius. Metode Penelitian Sosial (Edisi Revisi). Jakarta: Yayasan Pustaka Obor Indonesia. 2014.

Sudiarti, Sri. Fiqh Muamalah Kontemporer. Medan: FEBI-UIN SU Press. 2018.

Usman, Iskandar. Istihsan dan Pembaharuan Hukum Islam. Jakarta: Raja Grafindo Persada. 1994.

Wiroso. Produk Perbankan Syariah. Jakarta: LPFE Usakti, 2009. 